\title{
Evaluation of Calcine Disposition Path Forward
}

\author{
Steve Birrer
}

February 2003

Idaho National Engineering and Environmental Laboratory Bechtel BWXT Idaho, LLC 


\title{
Evaluation of Calcine Disposition Path Forward
}

\author{
Steve Birrer \\ Mike Heiser
}

February 2003

Idaho National Engineering and Environmental Laboratory Idaho Falls, Idaho 83415

\author{
Prepared for the \\ U.S. Department of Energy \\ Assistant Secretary for Environmental Management \\ Under DOE Idaho Operations Office \\ Contract DE-AC07-99ID13727
}




\begin{abstract}
This document describes an evaluation of the baseline and two alternative disposition paths for the final disposition of the calcine wastes stored at the Idaho Nuclear Technology and Engineering Center at the Idaho National Engineering and Environmental Laboratory. The pathways are evaluated against a prescribed set of criteria and a recommendation is made for the path forward.
\end{abstract}




\section{CONTENTS}

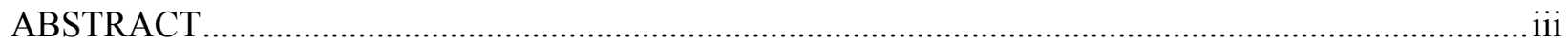

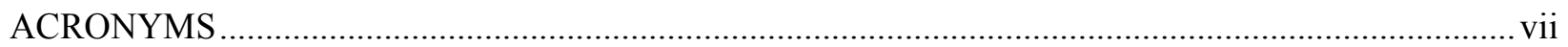

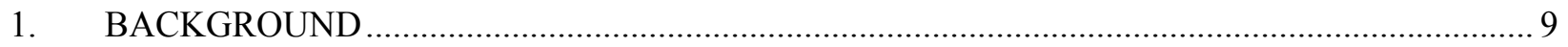

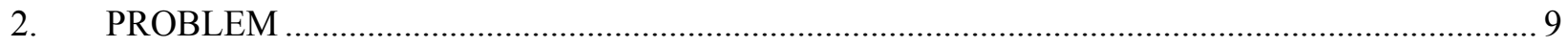

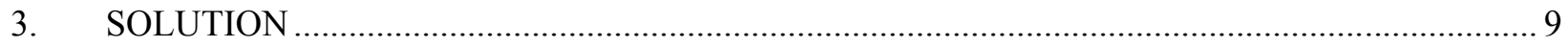

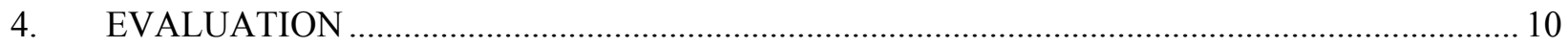

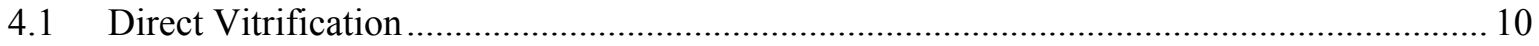

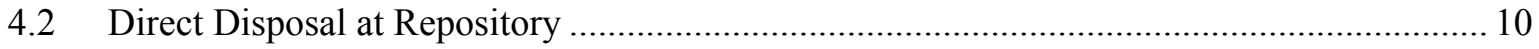

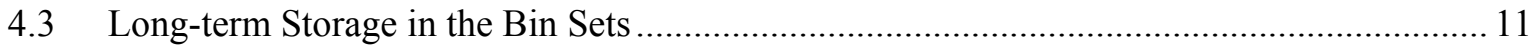

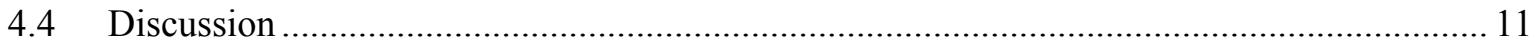

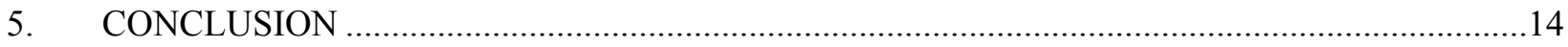

\section{FIGURES}

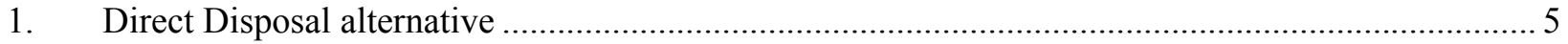




\section{ACRONYMS}

CSSF Calcine Solids Storage Facility

DOE Department of Energy

HLW high-level waste

HLW FD FEIS High-Level Waste Facilities Disposition Final Environmental Impact Statement

INEEL Idaho National Engineering and Environmental Laboratory

INTEC Idaho Nuclear Technology and Engineering Center

PMP Performance Management Plan

RCRA Resource Conservation and Recovery Act

SBW sodium-bearing waste

WIPP Waste Isolation Pilot Plant 


\section{Evaluation of Calcine Disposition Path Forward}

\section{BACKGROUND}

From 1952 to 1991, spent nuclear fuel was reprocessed at the Idaho Chemical Processing Plant. This facility, now known as the Idaho Nuclear Technology and Engineering Center (INTEC), is a part of the Idaho National Engineering and Environmental Laboratory (INEEL).

Reprocessing operations at INTEC used solvent extraction systems to remove primarily uranium-235 from spent nuclear reactor fuel and, in the process, generated liquid mixed highlevel waste (HLW) as well as other wastes. Between 1963 and 2000, this liquid HLW was fed to a treatment facility and converted to a dry granular substance called calcine. This treatment resulted in the generation of approximately 4,400 cubic meters of calcine that is currently being stored in bin sets at the Calcine Solids Storage Facility (CSSF) with a design life of 500 years. In 1995, the Department of Energy (DOE) and the State of Idaho reached an agreement called the Idaho Settlement Agreement/Consent Order that set a target date of December 31, 2035 by which time that this calcine would be made road-ready for shipment out of Idaho.

Consistent with this agreement, DOE has to analyze approaches to place the calcine in a form suitable for disposal in the national geologic repository. These approaches were evaluated and documented in the Idaho High-Level Waste and Facilities Disposition Final Environmental Impact Statement (Idaho HLW \& FD FEIS) (DOE/EIS-0287) issued in 2002.

\section{PROBLEM}

The current INEEL baseline is to vitrify the calcine to have it ready to ship to the repository by 2035 with actual shipments to complete by 2070 . While this baseline is compliant with the Idaho Settlement Agreement, it comes at a life-cycle cost of approximately \$7B.

\section{SOLUTION}

In May 2002, DOE, the Idaho Department of Environmental Quality, and the Environmental Protection Agency signed a letter of intent formalizing an agreement to pursue accelerated risk reduction and cleanup at the INEEL. In support of this agreement, DOE developed and issued the Environmental Management Performance Management Plan (PMP) for Accelerating Cleanup of the Idaho National Engineering and Environmental Laboratory (DOE/ID-11006, dated July 2002). The PMP describes DOE's approach to accelerate the reduction of environmental risk at the INEEL by completing its cleanup responsibility faster and more efficiently. It outlines nine strategic initiatives DOE proposes to meet this accelerated cleanup approach, including an initiative to accelerate HLW calcine removal from Idaho.

The accelerated strategy for calcine removal from Idaho is as follows:

- Complete characterization of calcine to support repository waste form acceptance criteria by 2012

- $\quad$ Complete construction of calcine retrieval and packaging facility by 2020

- $\quad$ Retrieve, stabilize, package, and ship calcine to the repository by 2035. 
This strategy would result in an overall acceleration of 35 years.

\section{EVALUATION}

To ensure success of this path forward, the calcine disposition project is conducting feasibility studies on the aspects of retrieving the calcine from the bin sets at the CSSF, stabilizing the calcine, determining the disposal canister for the calcine, and packaging the calcine. Based upon these studies, a facility will be built to retrieve, stabilize, package, and ship the calcine.

In support of the feasibility studies, the project has asked the Waste Management Technologies Department to prepare a brief evaluation of the current baseline as well as two alternative approaches to calcine disposition. A discussion of the three approaches follows.

\subsection{Direct Vitrification}

Direct vitrification, the current baseline approach, entails retrieval of the calcine from the bin sets, vitrifying it to a suitable form, temporary storage at the INEEL, and transport to an offsite storage facility or to the geologic repository for disposal. The life-cycle costs of this approach is approximately \$7B (escalated cost; as referenced in the PMP) plus an additional \$6-8.4B in disposal costs. This approach was selected by the State of Idaho as their preferred alternative for the Idaho HLW \& FD FEIS.

This alternative has several advantages as follows:

- $\quad$ Meets the Idaho Settlement Agreement

- $\quad$ Consistent with the Idaho HLW \& FD FEIS

- $\quad$ Meets the requirements of the Resource Conservation and Recovery Act (RCRA)

(although will require a delisting petition)

- $\quad$ Minimizes risk to the public, the environment, and to workers.

This alternative has two disadvantages as follows:

- $\quad$ Significant Calcine Disposal Project life-cycle costs

- $\quad$ Significant disposal costs.

\subsection{Direct Disposal at Repository}

This alternative entails retrieval of the calcine from the bin sets and preparation and packaging for just-in-time shipment to the geologic repository for disposal. The life-cycle cost of this approach is approximately $\$ 1.3 \mathrm{~B}$ (escalated cost; Appendix A) with an additional \$2-3B in disposal costs.

This alternative has several advantages as follows:

- $\quad$ Meets the Idaho Settlement Agreement 
- $\quad$ Consistent with the Idaho HLW \& FD EIS

- Meets the goals of accelerated cleanup

- Minimizes risk to the public, the environment, and to workers

- $\quad$ Significant cost savings

- $\quad$ Less personnel exposure.

This alternative has several disadvantages as follows:

- $\quad$ Requires some rulemaking changes to the RCRA regulations

- $\quad$ Mixed acceptance by stakeholders due to perceptions of risk.

\subsection{Long-term Storage in the Bin Sets}

This alternative entails long-term (500 years) storage in the bin sets prior to retrieval and packaging for shipment to a repository similar to Waste Isolation Pilot Plant (WIPP). This alternative assumes that the radioactive decay over this period of time would allow the waste to be classified and disposed of as contact-handled transuranic waste. The life-cycle cost of this approach, including disposal costs, is approximately \$2.1B (escalated cost; Appendix A).

This alternative has several advantages as follows:

- $\quad$ Significant cost savings and minimizes near-term costs

- $\quad$ Less personnel exposure.

This alternative has several disadvantages as follows:

- Does not meet RCRA regulatory framework

- Does not meet Idaho Settlement Agreement

- Does not meet goals of accelerated cleanup

- May result in suspension of DOE fuel shipments into Idaho per the Settlement Agreement, Section E.9.

\subsection{Discussion}

To capture the advantages and disadvantages of these alternatives in an easily understood manner, the Quick Compare decision analysis tool, developed at the INEEL, was used. This tool enables users to define goals/objectives and to evaluate alternatives against prescribed criteria. For this evaluation, the following nine criteria were used:

- $\quad$ Schedule 
- $\quad$ Calcine Disp. Project Costs

- Disposal Costs

- Technical Maturity

- $\quad$ Worker Safety and Health

- $\quad$ Risk to Public

- $\quad$ Risk to Environment

- Stakeholder Acceptance

- Regulatory Acceptance

- $\quad$ Site Consensus.

The results of the evaluation are shown in Figure 1.

As shown in Figure 1, the Direct Disposal alternative has the highest overall score (using equally weighted criteria) with the Direct Vitrification and the Long-Term Storage alternatives lagging significantly behind. Direct Disposal offers significant overall cost savings compared to the Direct Vitrification alternative. The Long-Term Storage alternative provides overall life-cycle cost savings over the Direct Disposal alternative yet has significant negative impact on the stakeholders, regulatory community, and other sites. If DOE were to select this alternative, it is almost certain that the State of Idaho would pursue legal challenges including an injunction against spent fuel shipments to the INEEL. This would force other sites to seek different disposition paths for their spent fuel at what is likely to be significant, unplanned costs. Additionally, this alternative assumes that a WIPP-like facility is already available and would not have to be designed and built. These costs were not included in the life-cycle estimates for this alternative. It is likely that these costs would more than offset the savings over Direct Disposal.

Explanations of the scoring logic are found in Attachment B.

A second set of outputs from this analysis is found in Appendix C. These sensitivity analysis charts show how the relative rankings of the alternatives vary as the weighting factor for a given criterion is increased. As seen in these charts, the Direct Disposal alternative is the preferred choice for most all scenarios. As higher priority is placed on stakeholder and regulatory acceptance, then the Direct Vitrification alternative becomes preferred. The Long-Term Storage alternative becomes the preferred choice when over $50 \%$ of the weighting are assigned to disposal costs. Due to the conservatism in the cost estimate for this alternative, the reality is that this alternative really only has value in its low near-term costs and technical maturity. 


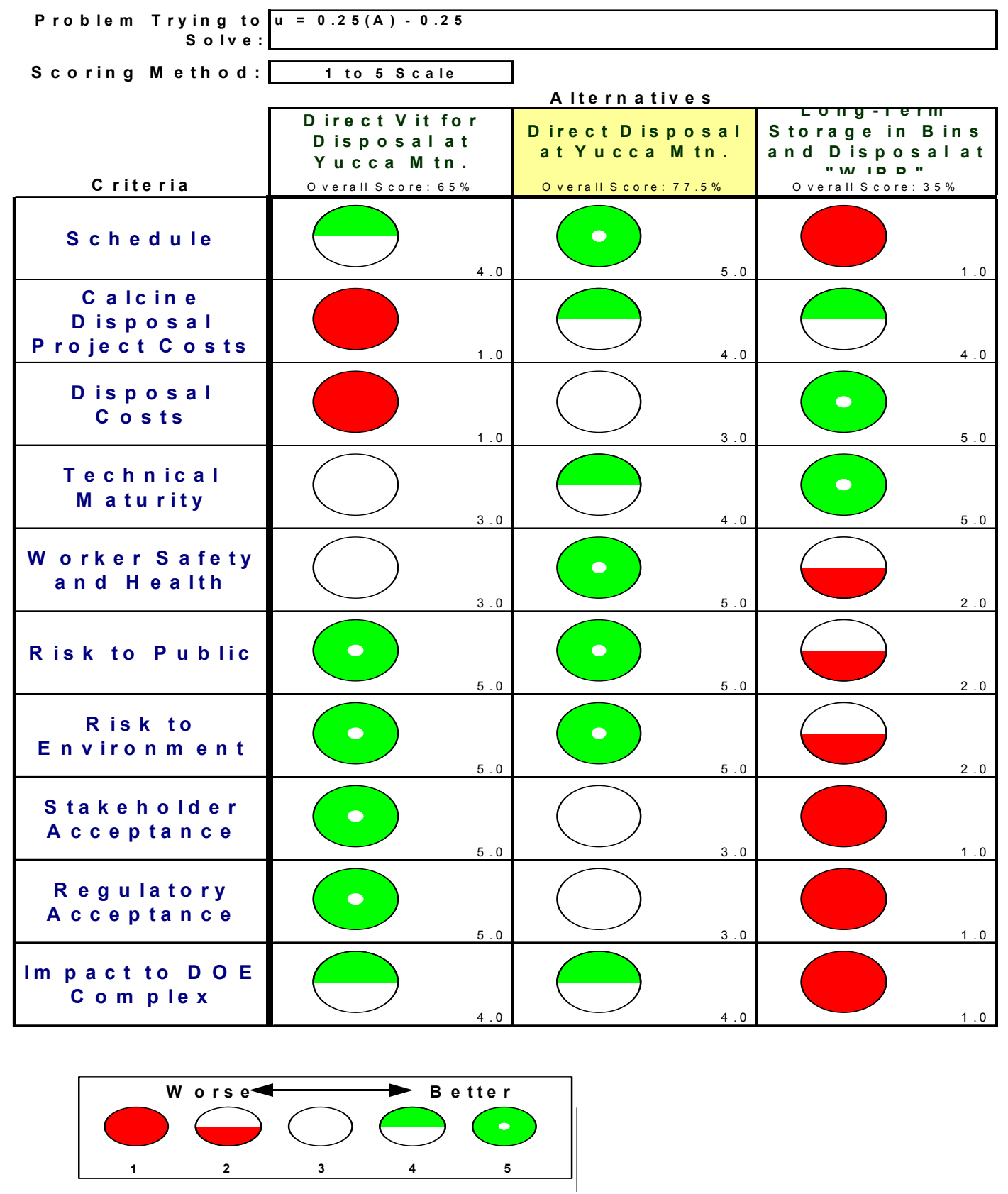




\section{CONCLUSION}

The Long-Term Storage alternative provides only marginal life-cycle cost savings over the Direct Disposal alternative, while creating very significant regulatory and political issues. It is recommended that this alternative not be considered for further evaluation. The calcine project should proceed forward with evaluating how to retrieve the calcine and place it into a form suitable for disposal at the repository (as defined in the Idaho HLW and FD EIS and the PMP). 
Appendix A

Life-cycle Cost Estimates 


\title{
Appendix A \\ Life-cycle Cost Estimates
}

\section{Direct Vitrification}

\author{
Calcine Project Cost $\quad=\$ 7 \mathrm{~B}$ per the PMP \\ Disposal Costs $\quad=\$ 6-8.4 \mathrm{~B}([12,000 \mathrm{cans}]$ [\$500-700K disposal fee $/ \mathrm{can}])$ \\ Total Life-cycle Costs $=\$ 13-15.4 \mathrm{~B}$
}

\section{Direct Disposal}

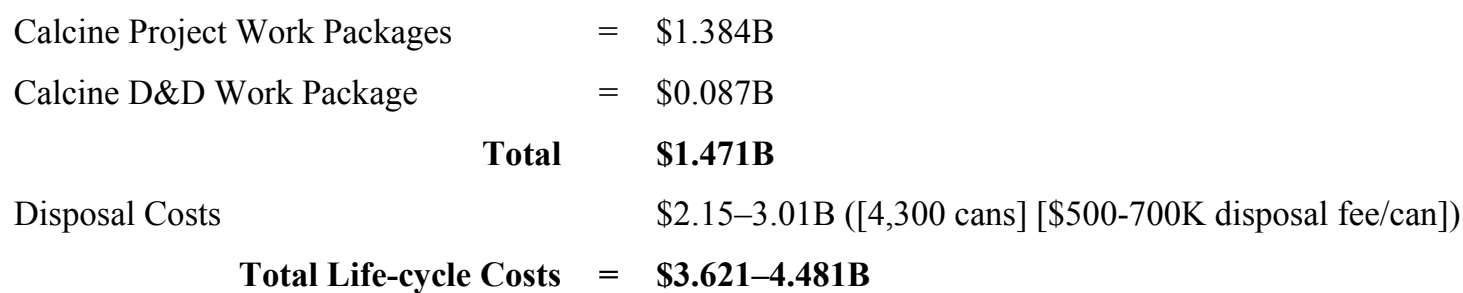

\section{Long-Term Storage}

Assume that the cost of this option, for the retrieval through shipping activities, is $50 \%$ of the Direct Disposal cost since the waste will decay to levels allowing handling as CH-TRU.

\footnotetext{
Calcine Project Work Packages at 50\% $=\$ 0.692 \mathrm{~B}$

Calcine D\&D Work Package at 50\% $=\$ 0.044 \mathrm{~B}$

Long-term operation

$=\$ 0.141 \mathrm{~B}$ (using current Surveillance and Maintenance of $\$ 0.3 \mathrm{M} / \mathrm{yr}$ for additional 470 years)

INTEC "hotel" load $\quad=\$ 1.293 \mathrm{~B}$ (assumes $10 \%$ of current yearly cost of $\$ 27.5 \mathrm{M} / \mathrm{yr}$ for 470 years)

Total $=\$ 2.170 \mathrm{~B}$

Disposal Costs

$=\$ 3 \mathrm{M}([4,400$ cubic meters of waste $][$ drum $/ 0.21$ cubic meters of waste] [\$150 disposal cost/drum])

Total Life-cycle Costs $=\$ 2.173 B$

NOTE: Cost data was taken from current figures in the Cobra financial system. Yucca Mountain disposal costs were supplied by the Calcine Disposal Project. WIPP disposal costs were taken from a similar study conducted on disposal of sodium-bearing waste (SBW) at WIPP.
} 


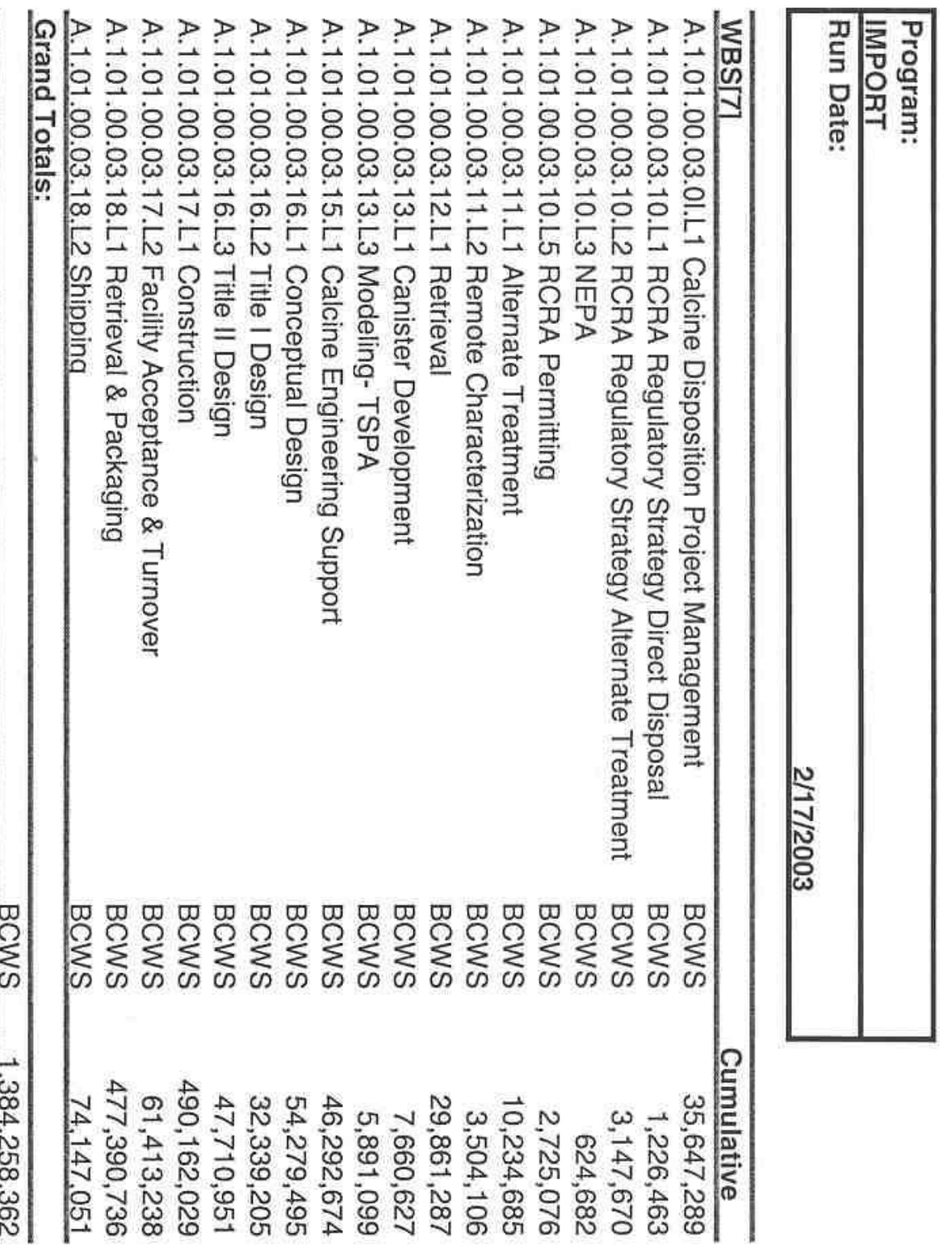




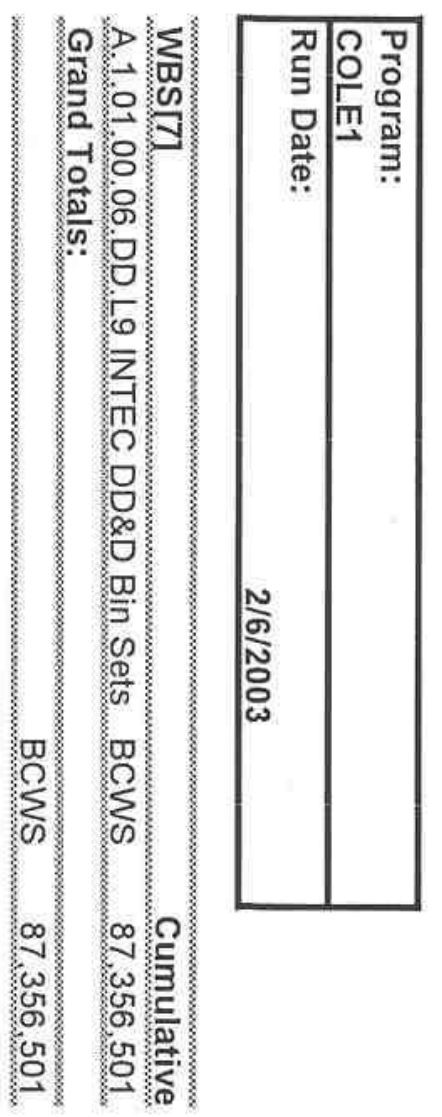


Appendix B 


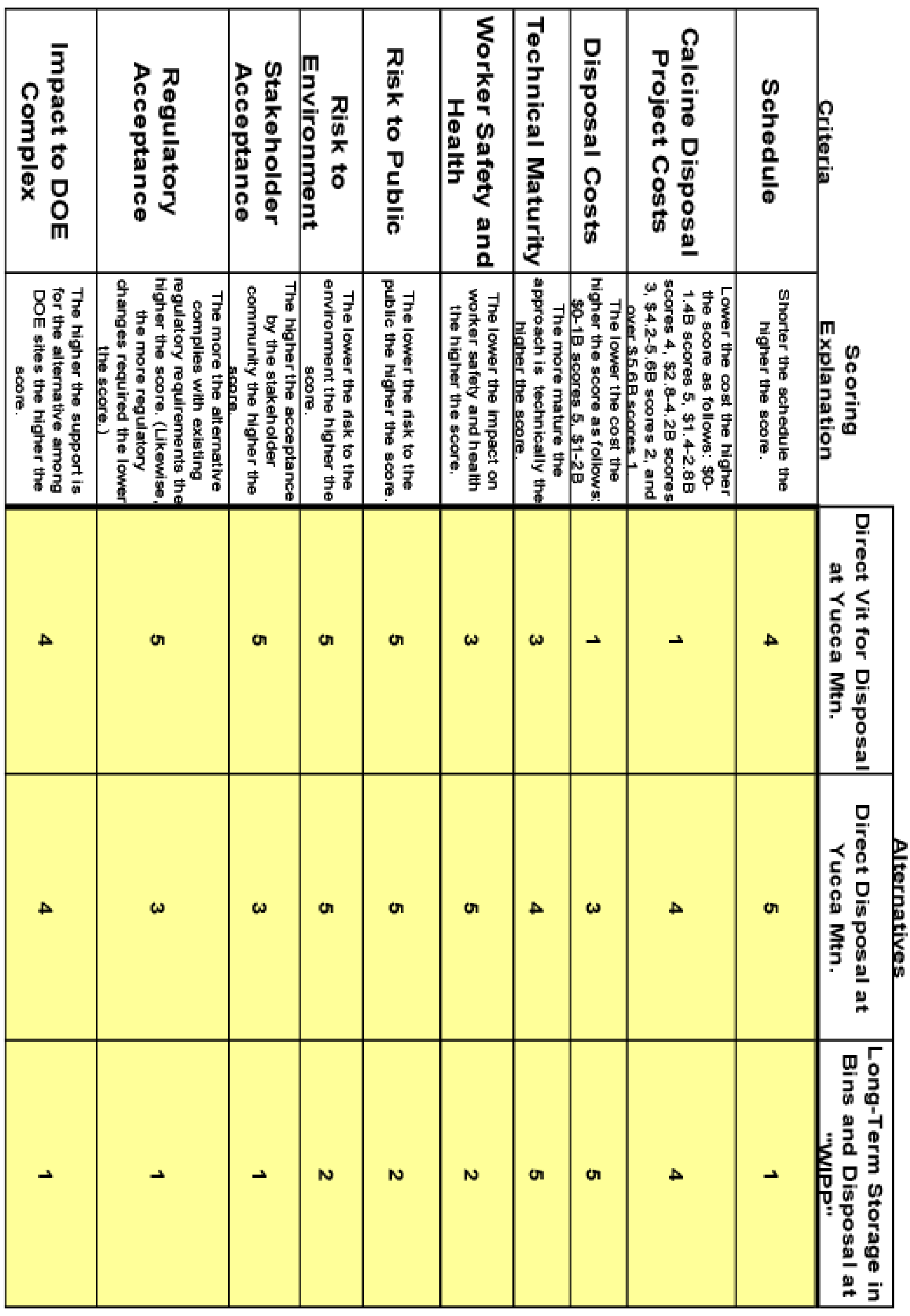




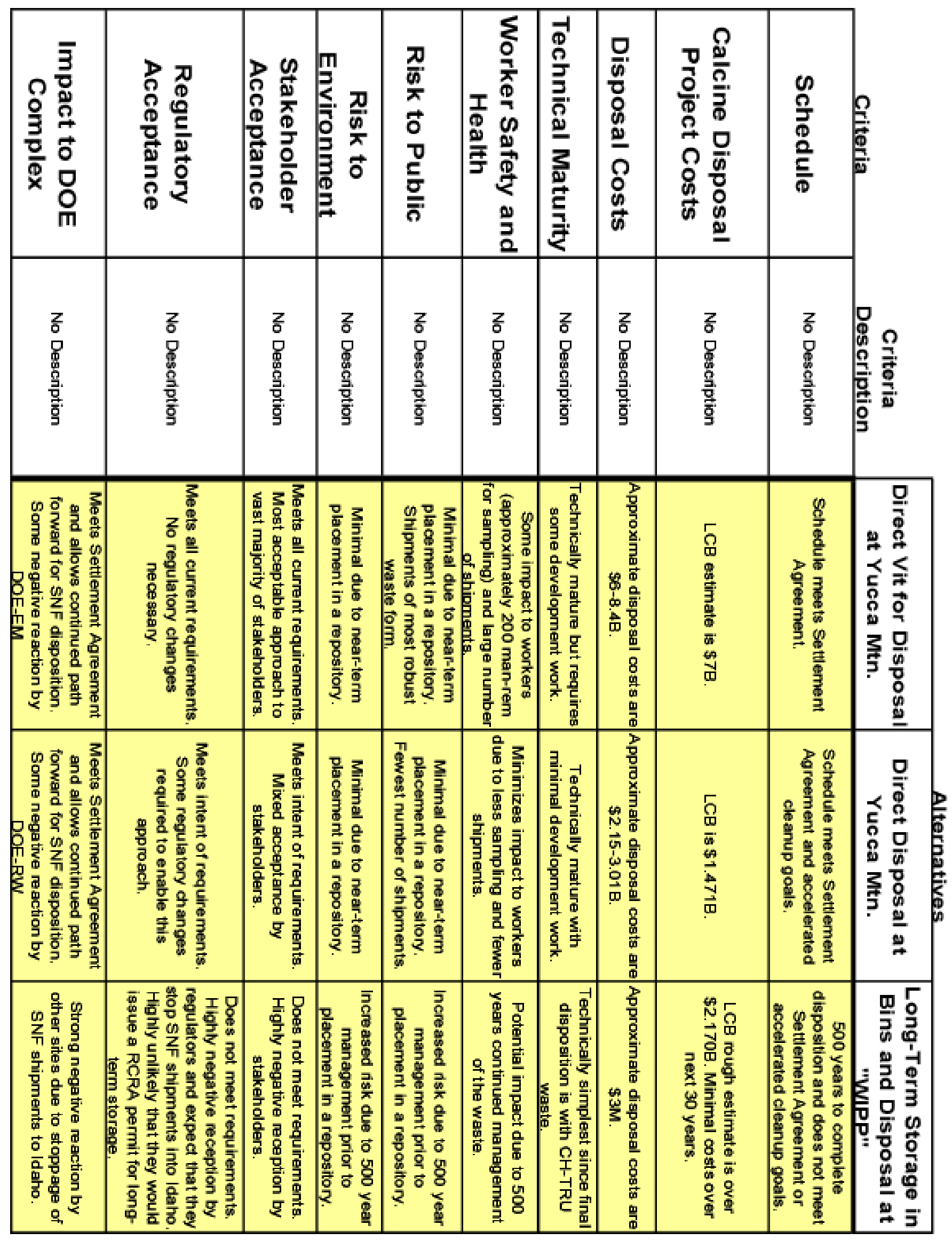




\section{Appendix C}

Criteria Sensitivity Analysis Charts 


\section{Appendix C}

\section{Criteria Sensitivity Analysis Charts}

The sensitivity analysis charts reflect the performance of each alternative as the weight of the criteria being considered is changed. For the initial review, equal weighting was used for each of the ten criteria (a weight of 0.1 each). As the weight for the criteria being evaluated is increased, the weights of the other criteria are summarily reduced such that the total weight still equals 1 . For example, if a weight of 0.5 is applied to cost, the remaining nine criteria are given a weight of 0.055 each.

These analyses quickly show the reader whether an alternative improves or declines in performance as a criteria increases in importance. 


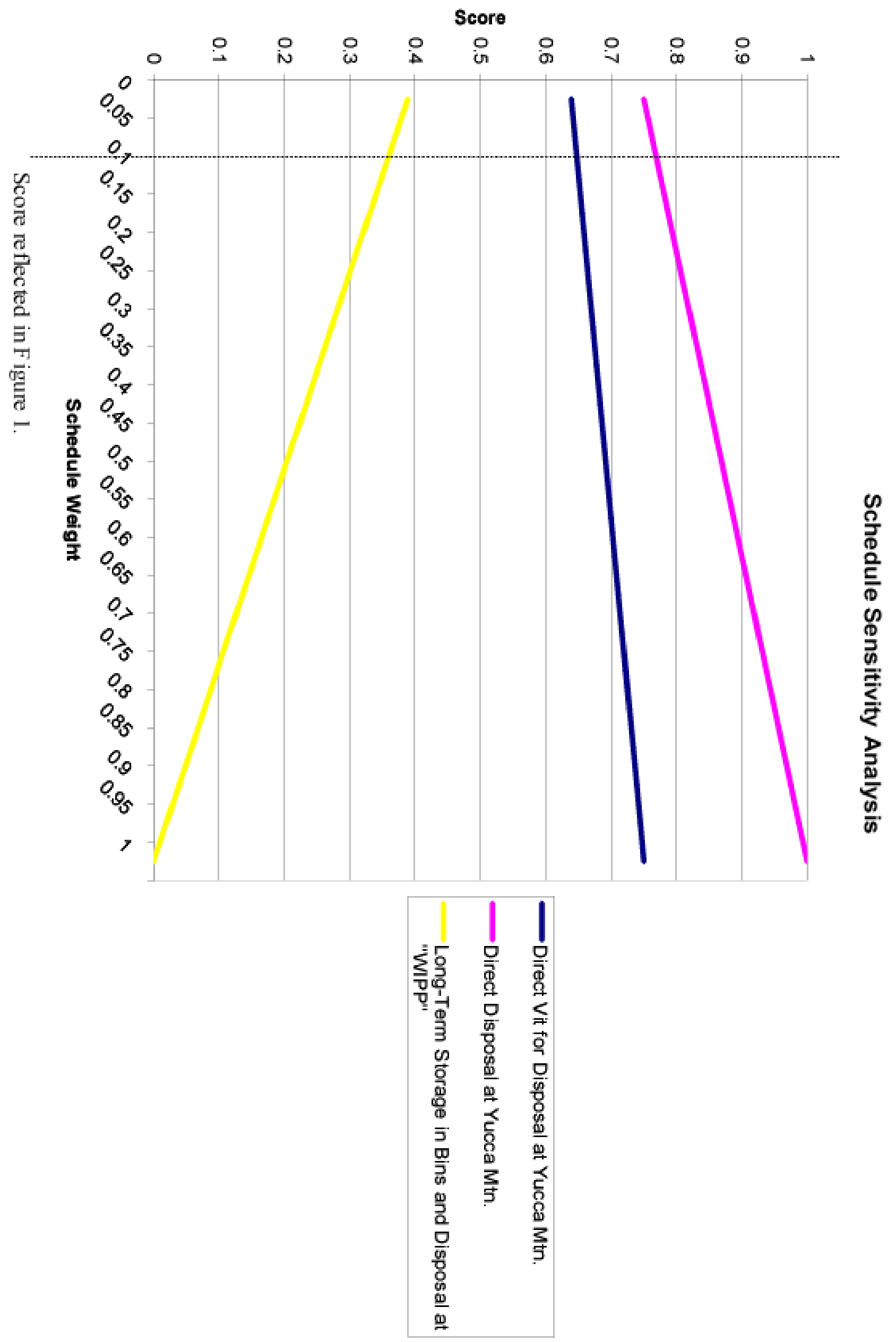




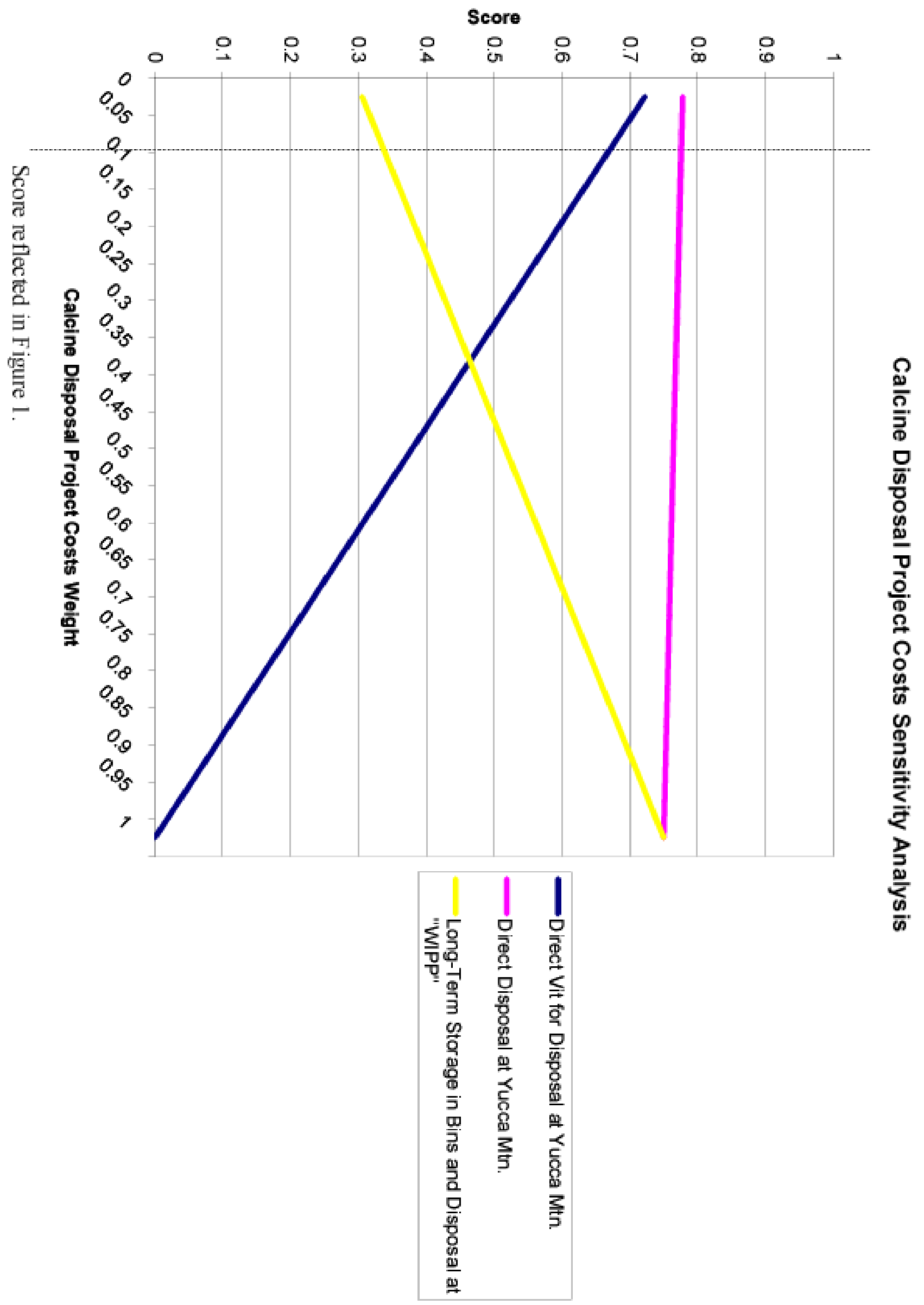




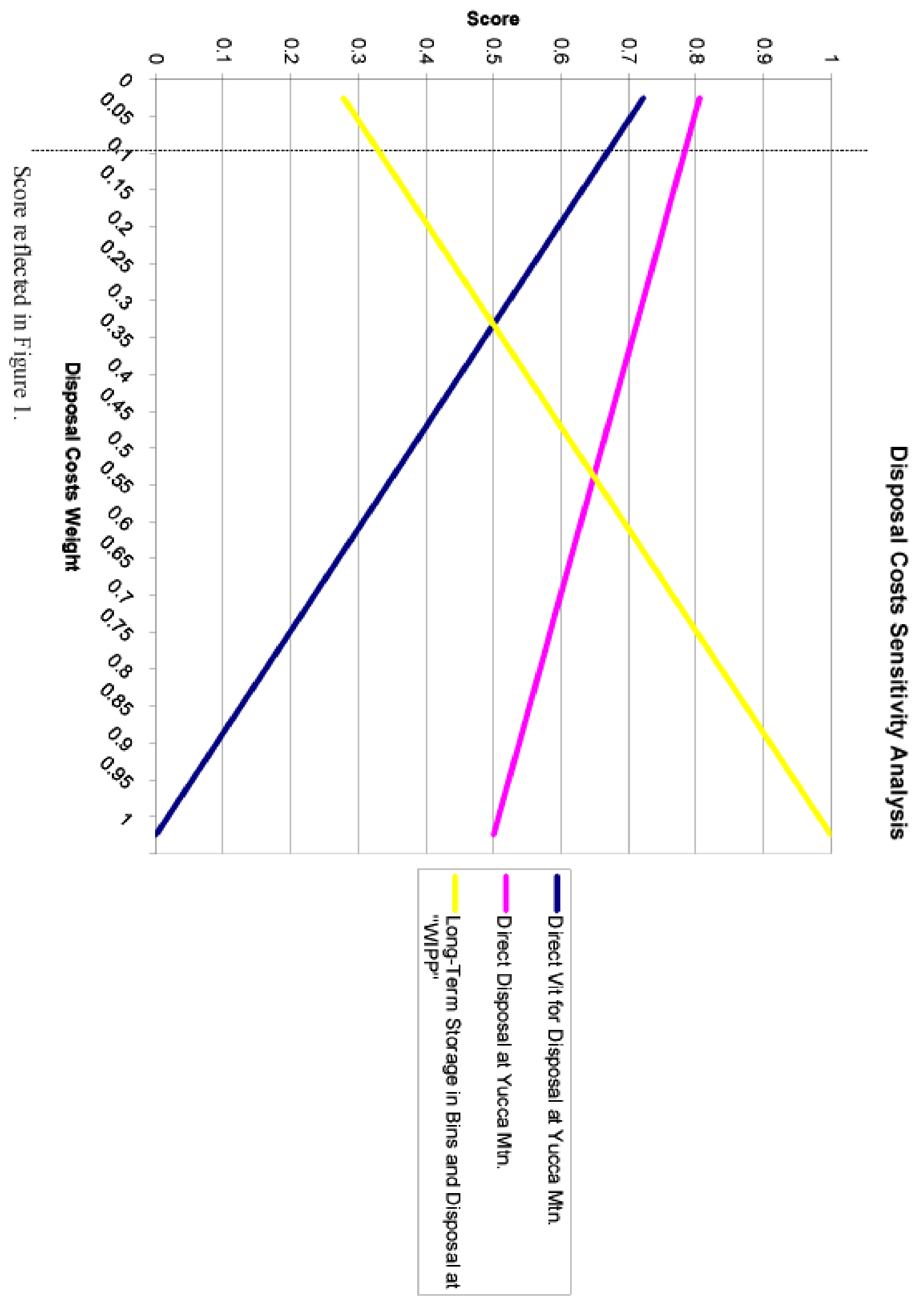




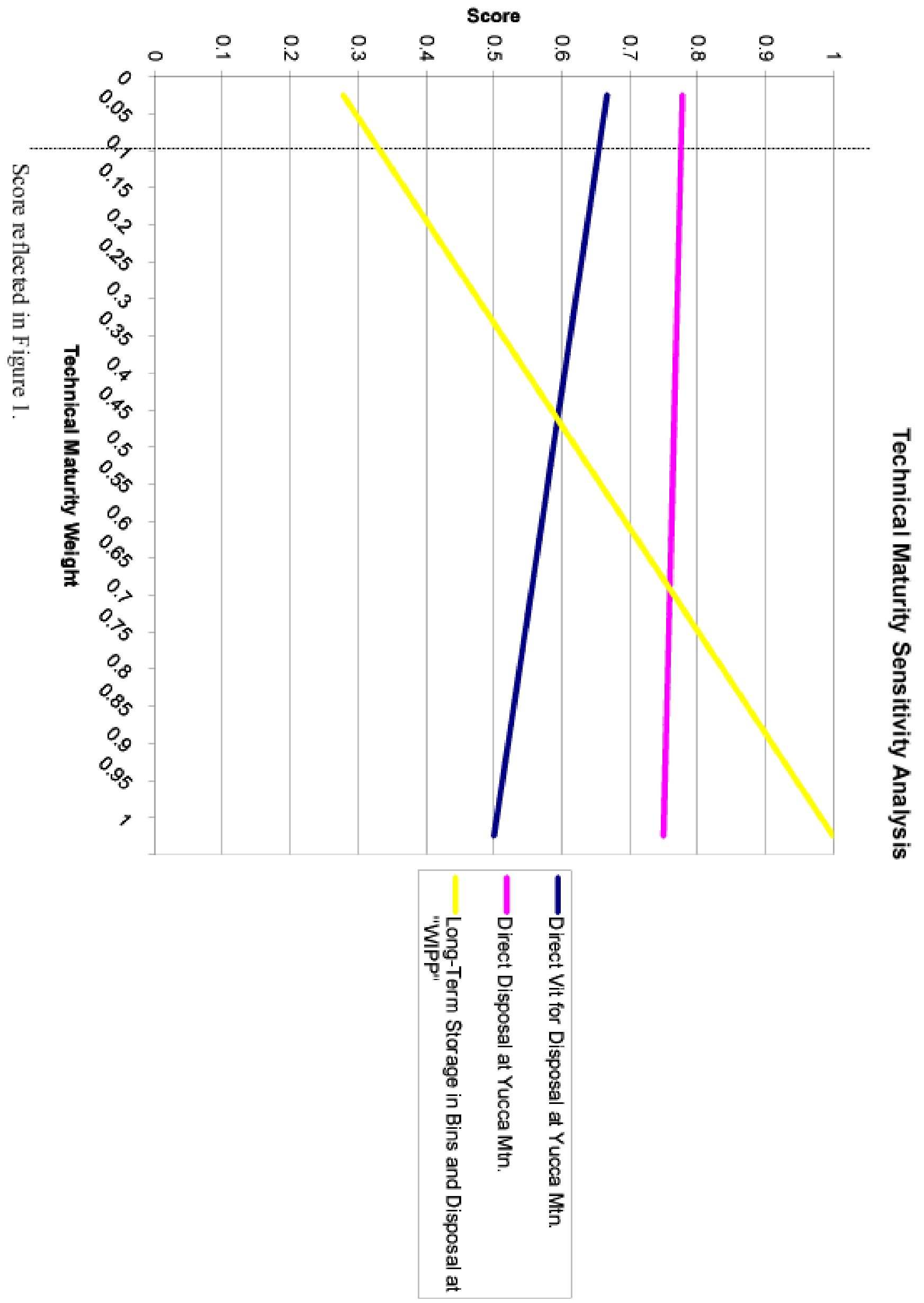




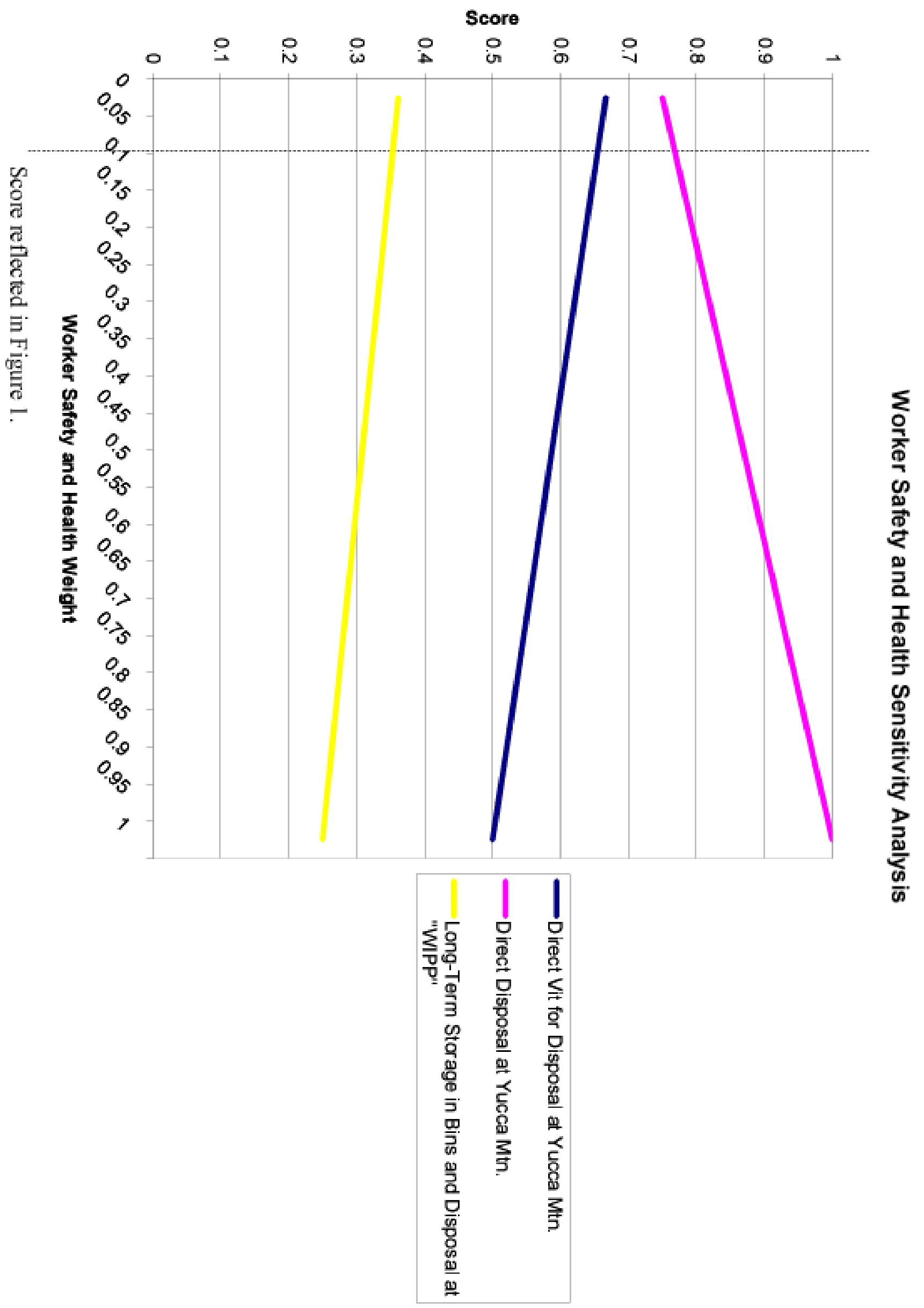




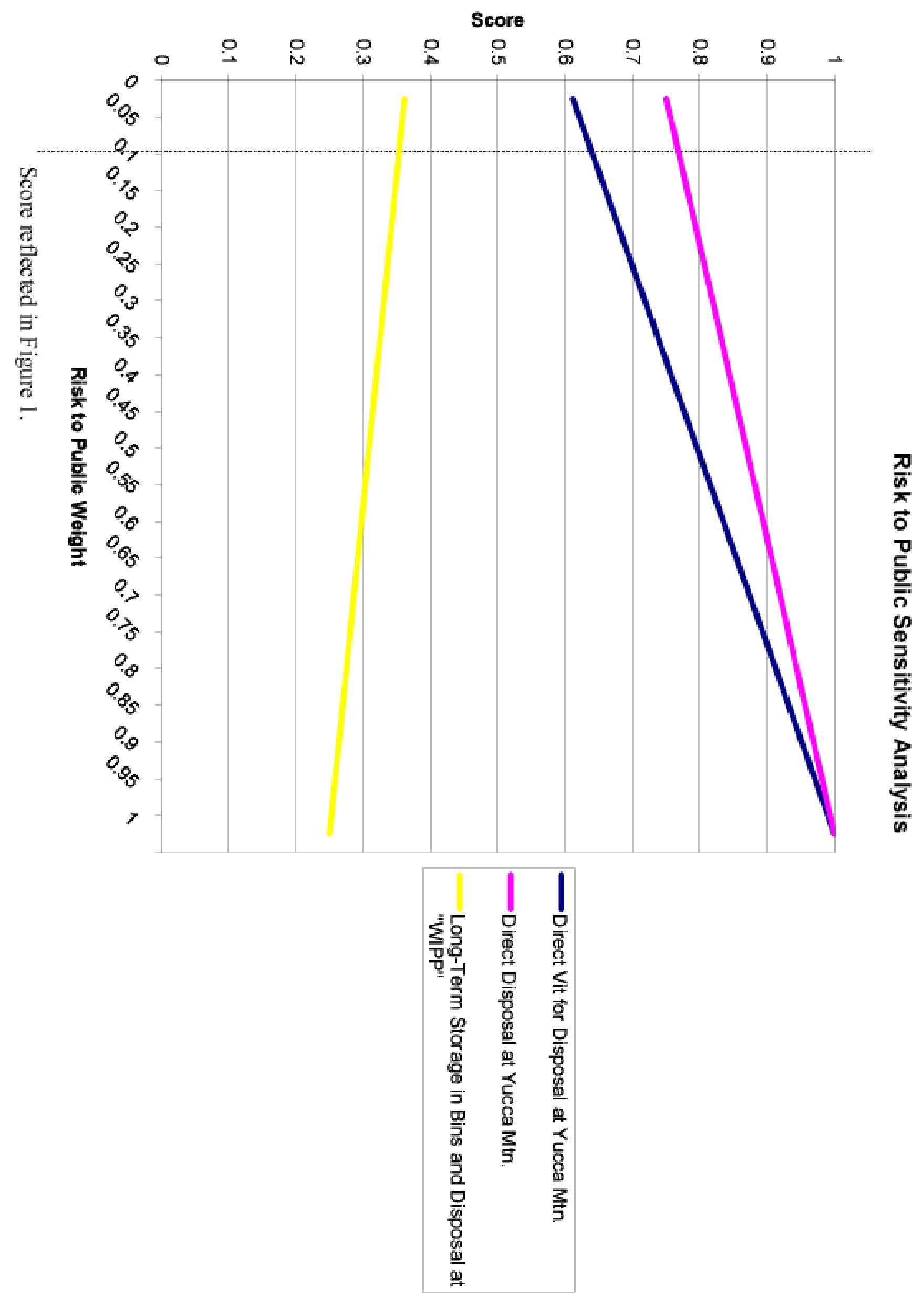




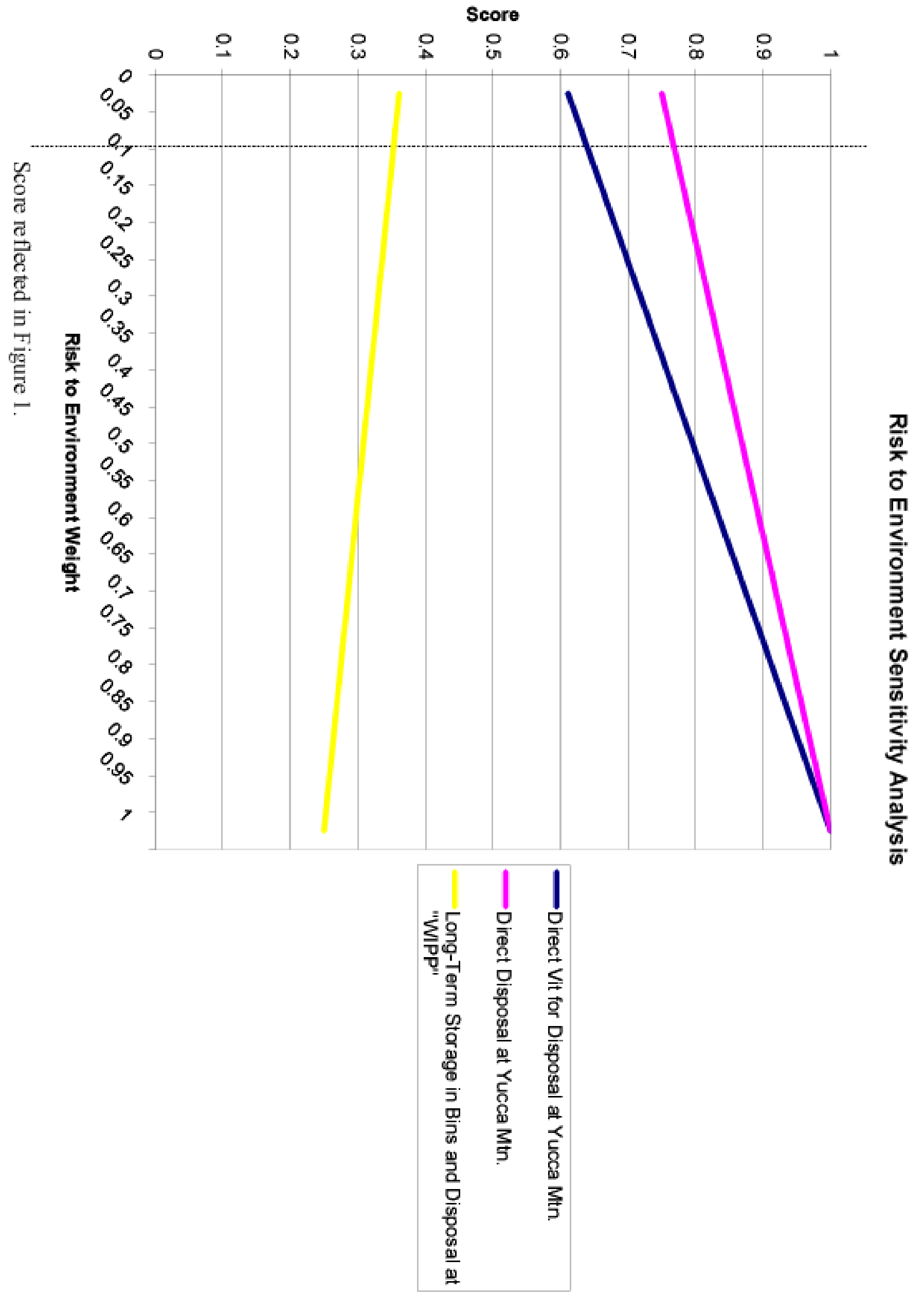




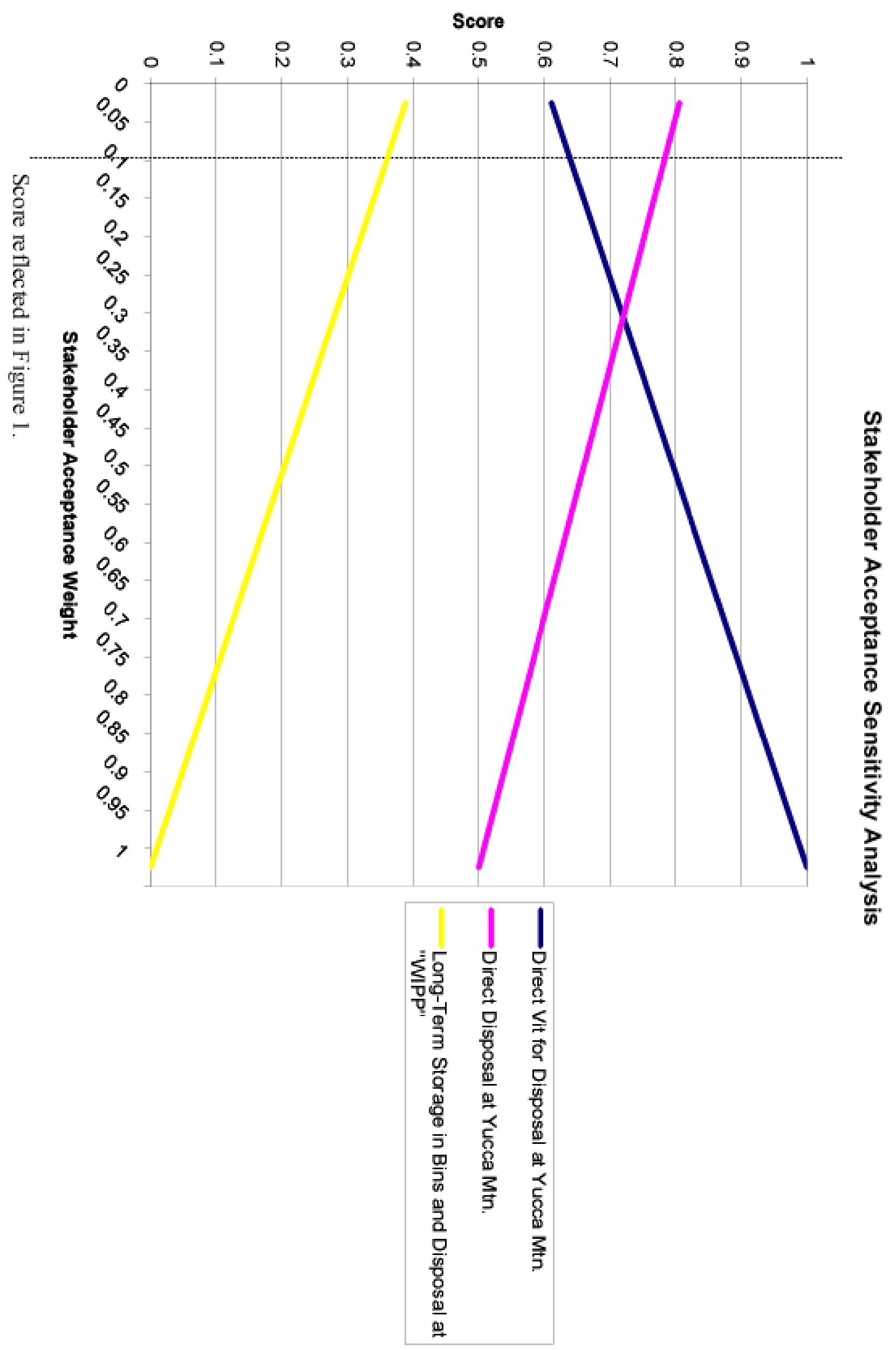




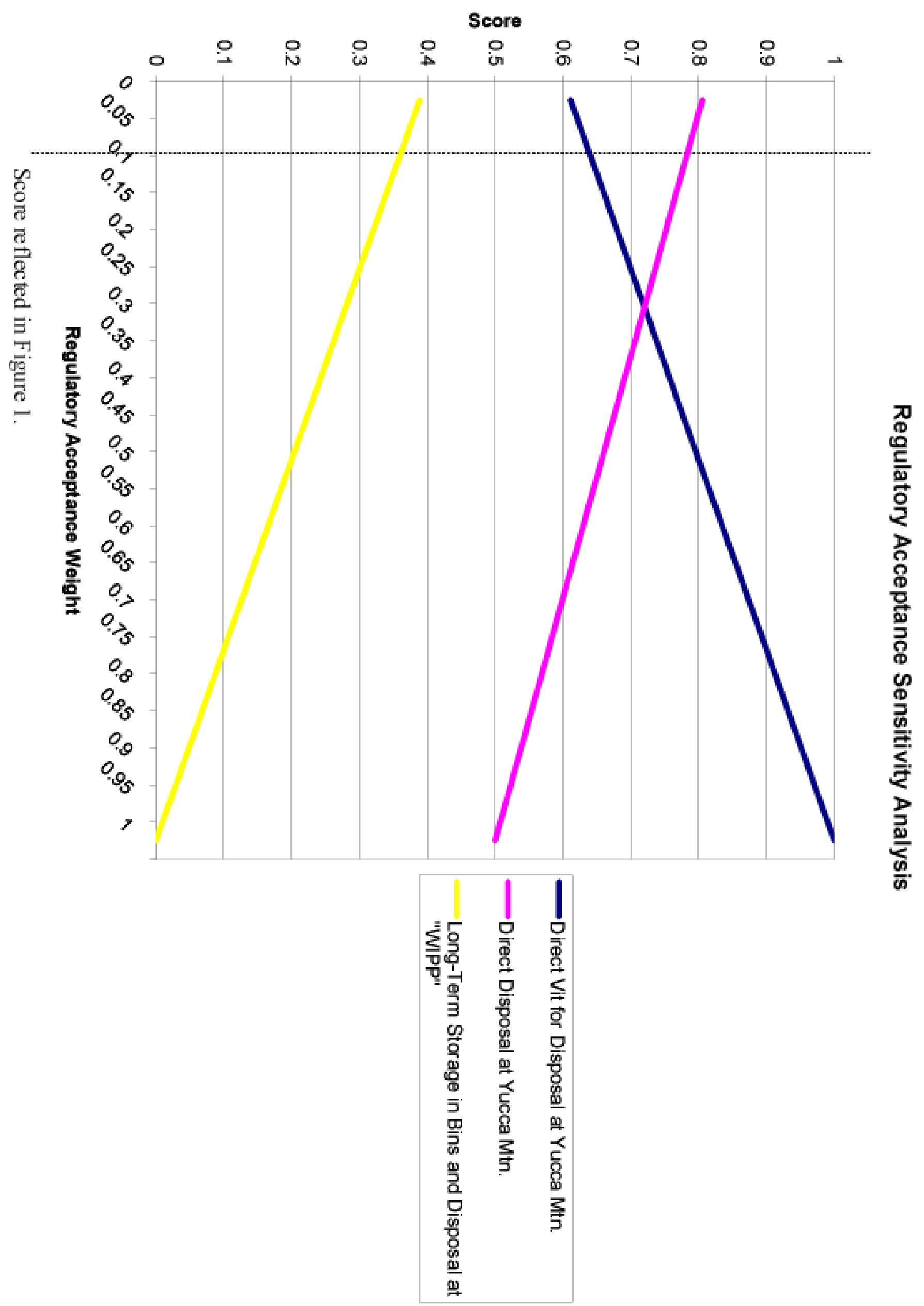




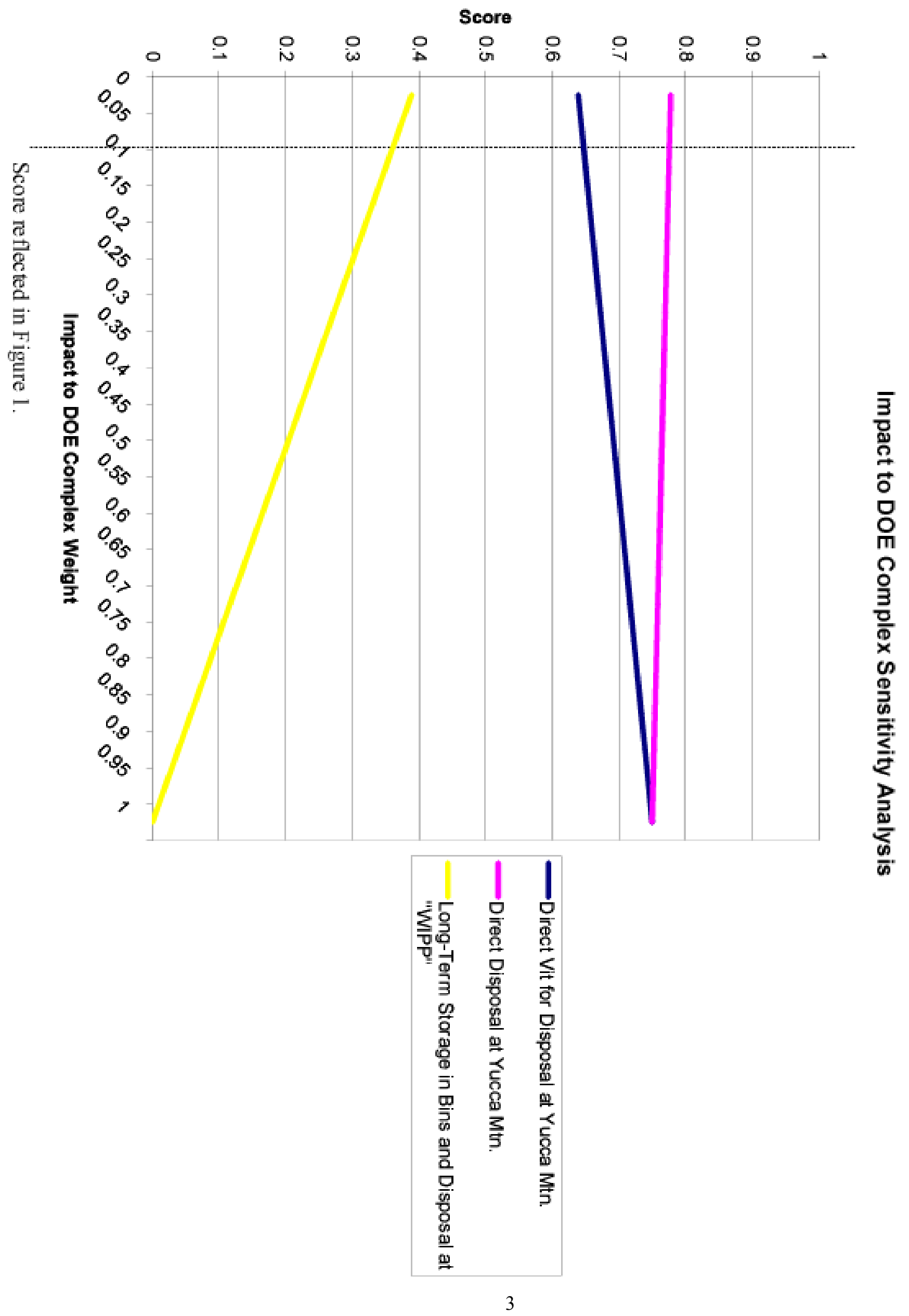

